\title{
Opstrukcija dišnog puta uzrokovana laringokelom - prikaz slučaja
}

\section{Airway obstruction caused by laryngocele - case report}

\author{
Luciana Miljas $^{1^{*}}$, Mario Milotić ${ }^{1}$, Blažen Marijić2 ${ }^{2}$ Jelena Vukelić ${ }^{2}$, Tamara Braut ${ }^{2}$
}

${ }^{1}$ Sveučilište u Rijeci, Medicinski fakultet, Rijeka

${ }^{2}$ Klinika za otorinolaringologiju i kirurgiju glave i vrata, KBC Rijeka, Rijeka

\section{"Dopisni autor:}

Luciana Miljas

Sveučilište u Rijeci, Medicinski fakultet e-mail: lucianamiljas@gmail.com
Sažetak. Cilj: Cilj rada je prikazati slučaj s višestrukim rijetkim komplikacijama laringokele. Prikaz slučaja: Prikazujemo slučaj 71-godišnje pacijentice s višestrukim komplikacijama laringokele. Pacijentica se prvi put javlja u kliniku za otorinolaringologiju i kirurgiju glave i vrata KBC-a Rijeka u veljači 2008. te biva podvrgnuta traheotomiji zbog epizode akutnog epiglotitisa. Godinu dana kasnije pacijentica se vraća na kliniku zbog odinofagije i disfagije. Postavlja se dijagnoza parafaringealnog apscesa te se on incidira i drenira. Godine 2010. pacijentica biva ponovno hospitalizirana zbog mase na vratu te se započinje $s$ dijagnostikom. Nekoliko dana kasnije pacijentica se otpušta, ali se ubrzo samoinicijativno vraća na kliniku dispnoična. Učini se magnetska rezonancija vrata i postavi se dijagnoza laringokele koju se liječi kirurškom ekstirpacijom. Zaključak: Naša pacijentica prezentira se nizom zanimljivih i vrlo rijetkih komplikacija koje čine ovaj slučaj vrijednim prikazivanja. Pretpostavljamo da je pacijentica u ovom slučaju laringokelu razvila zbog traheotomije 2008. godine. Pretražujući literaturu, pronašli smo samo jedan slučaj koji povezuje traheotomiju s nastajanjem laringokele. Nadalje, laringokela je pacijentici uzrokovala po život opasnu opstrukciju dišnog puta, što je samo po sebi vrlo rijetka komplikacija. Možemo pretpostaviti da bi ranija dijagnoza i adekvatno liječenje omogućilo ovoj pacijentici da izbjegne sve komplikacije te se nadamo kako će ovaj slučaj podići svijest o laringokeli i smanjiti incidenciju komplikacija u budućnosti.

Ključne riječi: dispneja; laringokela; traheotomija

Abstract. Objective: The aim of this case report is to present a case with multiple rare laryngocele complications. Case review: This case report follows a 71-year-old female patient with multiple complications following the formation of a laryngocele. The patient first arrives at the Otorhinolaryngology, head and neck surgery clinic in February 2008 and undergoes a tracheotomy for acute epiglottitis. A year later, the patient returns to the clinic complaining about odynophagia and dysphagia. A diagnosis of parapharyngeal abscess is made and the patient is treated with incision and drainage. In 2010 the patient is re-hospitalized for a neck formation and a diagnostic procedure is initiated. A few days later, the patient is discharged, but soon returns to the hospital dyspnoeic. Magnetic resonance imaging of the neck is performed, and a diagnosis of laryngocele is made. The patient undergoes surgical extirpation of the laryngocele. Conclusion: The patient in this case has an interesting combination of rare complications which makes this case worth representing. Firstly, we assume that this patient has developed a laryngocele following a tracheostomy. We were able to find only one case of post-tracheostomy laryngocele formation in the literature. Secondly, the laryngocele caused this patient a life threating airway obstruction which is in itself a very rare complication. We can speculate that an earlier diagnosis and treatment could have saved the patient of all the complication she had, and we hope this case can contribute to lower the incidence of laryngocele complications in the future.

Key words: dyspnea; laryngocele; tracheotomy 


\section{UVOD}

Laringokela je cistično izbočenje sluznice grkljana ispunjeno zrakom. Može nastati kao kongenitalna ili stečena anomalija. To je izuzetno rijetko stanje te većinom ne uzrokuje nikakve simptome već se otkrije kao slučajni nalaz. Češća je u bijelaca starijih od 50 godina. Najčešći rizični faktori za nastanak laringokele uključuju učestali kašalj, opstruktivne lezije grkljana, starenje te određena zanimanja (svirači puhačkih instrumenata te puhači stakla) ${ }^{1-4}$. S obzirom na lokalizaciju postoje 3 vrste laringokela. Unutarnje laringokele prominiraju u sam lumen grkljana i mogu uzrokovati simptome promuklosti, kašlja ili pak opstrukcije dišnog puta. Vanjske laringokele sežu preko tireohioidne membrane te se mogu prezentirati kao novotvorine na vratu. Miješane laringokele uključuju karakteristike i vanjske i unutarnje. Ako dođe do infekcije laringokele te nakupljanja gnoja, razvija se laringopiokela ${ }^{5,6}$.

Prikazujemo slučaj 74-godišnje pacijentice kojoj je dijagnoza laringokele postavljena nakon 4 hospitalizacije i niza rijetkih komplikacija.

\section{PRIKAZ SLUČAJA}

$U$ veljači 2008. godine na Klinici za otorinolaringologiju (ORL) i kirurgiju glave i vrata hospitalizira se 71-godišnja pacijentica u hitnoći zbog otežanog i stridoroznog disanja. Pacijentica od ranije boluje od dijabetesa i hiperlipidemije. Indirektnom laringoskopijom postavi se dijagnoza akutnog epiglotitisa te se hitno ordinira antiedematozna terapija. Na primijenjenu terapiju ne dolazi do poboljšanja. Zbog respiratorne insuficijencije učini se hitna traheotomija. Po provedenom liječenju dolazi do poboljšanja te se u daljnjem tijeku učini dekanilman. $U$ prosincu 2009. godine pacijentica se ponovno javlja na kliniku za ORL zbog disfagije i odinofagije. Kliničkim pregledom ustanovi se edem u lumenu grkljana. Postavi se dijagnoza parafaringealnog apscesa te se ordinira antibiotska i antiedematozna terapija. Osmog dana hospitalizacije učini se incizija apscesa mikrolaringoskopskim pristupom te se dobiveni sekret pošalje na mikrobiološku analizu. Tijekom hospitalizacije vrše se svakodnevne dilatacije incizije. Po smirivanju upale i poboljšanju općeg stanja pacijentica se otpušta kući.
U studenom 2010. pacijentica je hospitalizirana na ORL po treći put zbog dijagnostičke obrade tvorbe grkljana. Magnetska rezonancija (MRI) vrata pokazuje tvorbu koja odgovara miješanoj laringokeli. Pacijentica se otpušta na kućnu njegu uz zakazan operativni zahvat, no javlja se 4. dan po otpustu zbog otežanog disanja te se ponovo hospitalizira. Učini se direktoskopija s incizijom apscesa te se svakodnevno vrši dilatacija incizije. Trinaest dana kasnije po smirivanju upale u općoj endotrahealnoj anesteziji učini se ekstirpacija la-

Laringokela je cistično izbočenje sluznice grkljana ispunjeno zrakom. Može nastati kao kongenitalna ili stečena anomalija. To je izuzetno rijetko stanje te većinom ne uzrokuje nikakve simptome, već se otkrije kao slučajni nalaz. Češća je u bijelih muškaraca iznad 50. godine života.

ringokele i preventivna traheotomija. Jedanaesti poslijeoperacijski dan lokalni nalaz zadovoljava te se pacijentica otpušta na kućnu njegu.

\section{RASPRAVA}

Laringokela je općenito vrlo rijetka patologija s incidencijom od 1 : 2500000 ljudi godišnje², a zanimljivost našeg slučaja leži u tome da su se vrlo rijetke pojave vezane za laringokelu pojavile kod istog pacijenta. lako razni stečeni i okolišni faktori mogu pogodovati razvoju laringokele, kao što su starija životna dob, neoplazme te određena zanimanja, poput puhača stakla ili svirača puhaćih instrumenata ${ }^{4,7}$, naša pacijentica nije imala nijednu od navedenih predispozicija. No, ona je dijabetičarka. Dijabetes može pridonijeti slabosti stijenke grkljana i otežanom cijeljenju ${ }^{8}$, a kako je pacijentica starija dijabetičarka s pozitivnom anamnezom traheotomije, vrlo je izgledno da je kod naše pacijentice traheotomija iz 2008. uzrokovala nastanak laringokele. Pretraživanjem dostupne literature pronašli smo još samo jedan rad koji povezuje nastanak laringokele $s$ traheotomijom, a kako bismo s većom sigurnošću mogli kauzalno povezati laringotomiju i laringokelu, potrebna su dodatna istraživanja.

Nadalje, laringokela je najčešće asimptomatska te se uobičajeno dijagnosticira slučajno. U ovom 
slučaju ona je uzrokovala simptome dispneje i opstrukcije dišnog puta. Iduća rijetka pojava je infekcija laringokele i nastanak laringopiokele. Upile i suradnici u svom radu iz 2018. opisuju laringopiokelu kao vrlo rijetku pojavu s oko 40 prijavljenih slučajeva u literaturi i samo 4 slučaja s razvojem akutne opstrukcije dišnih putova ${ }^{9}$.

Tijekom akutnih prezentacija, početni tretman laringopiokele uključuje drenažu koja smanjuje učinak mase u grkljanu i sprječava rupturu i udisanje gnoja. Također se primjenjuju širokospektralni

Laringokela je izuzetno rijetka pojava koja može uzrokovati opstrukciju dišnog puta. Pravovremenim prepoznavanjem te intervencijama može se izbjeći pojava komplikacija te po život opasna stanja.

antibiotici, a konačna terapija je ekscizija tvorbe da bi se prevenirale daljnje komplikacije ${ }^{10-11}$. Kod naše pacijentice provedena je antibiotska terapija i incizija tvorbe, te je u konačnici provedena i ekstirpacija laringokele. U prikazanom slučaju ranija dijagnoza laringopiokele te konačna kirurška ekstirpacija omogućila bi da se izbjegne ponovna hospitalizacija.

\section{ZAKLJUČAK}

Zaključno, laringokela je izuzetno rijetka pojava s incidencijom 1 : 2500 000. U nekim slučajevima može uzrokovati potencijalno letalnu opstrukciju dišnog puta, što je bio slučaj kod naše pacijentice. Unatoč rijetkoj pojavnosti, diferencijalno dijagnostički je valja uvijek uzeti u razmatranje kada se pacijent prezentira perzistirajućom disfagijom i/ili odinofagijom te tumorom vrata. Pravovremenim prepoznavanjem te intervencijama može se izbjeći pojava komplikacija te po život opasna stanja.

Izjava o sukobu interesa: Autori izjavljuju da nemaju sukob interesa.

\section{LITERATURA}

1. Vardhan Reddy MV, Ramakrishna C, Gupta M, Babu AS, Shankar T, Singh R et al. Laryngocele - A Case Report and Review of Literature. Indian J Otolaryngol Head Neck Surg 2008;60:281-3.

2. Lancella A, Abbate G, Dosdegani R. Mixed laryngocele: a case report and review of the literature. Acta Otorhinolaryngol Ital 2007;27:255-7.

3. Spinosi MC, Mezzedimi C, Monciatti G, Passali D. Internal laryngocele: Unusual onset in a 91-year-old female patient. Sultan Qaboos University Med J 2018;18:104.

4. Suqati AA, Alherabi AZ, Marglani OA, Alaidarous TO. Bilateral combined laryngocele. Saudi Med J 2016;37:902-4.

5. Mobashir MK, Basha WM, Mohamed AE, Hassaan M, Anany AM. Laryngoceles: Concepts of diagnosis and management. Ear Nose Throat J 2017;96:133-8.

6. Aslaner MA. Laryngopyocele: A deep neck infection diagnosed by emergency ultrasound. Am J Emerg Med [Internet]. 2018;36. [cited 2019 Aug 22]. Available from: https://www.ajemjournal.com/article/S07356757(18)30661-2/fulltext

7. Lam SY, Lau HY. A Rare Case of Laryngopyocele with Airway Obstruction. J Clin Imaging Sci 2018;8:42.

8. Tellechea A, Leal EC, Kafanas A, Auster ME, Kuchibhotla S, Ostrovsky Y, et al. Mast Cells Regulate Wound Healing in Diabetes. Diabetes 2016;65:2006-19.

9. Upile T, Jerjes W, Sipaul F, Maaytah ME, Singh S, Howard $D$, et al. Laryngocele: a rare complication of surgical tracheostomy. BMC Surg 2006;6:14.

10. Zelenik K, Stanikova L, Smatanova K, Cerny M, Kominek P. Treatment of Laryngoceles: What Is the Progress over the Last Two Decades? Biomed Res Int [Internet]. 2014; 2014. [cited 2019 Aug 29]. Available from: https://www. hindawi.com/journals/bmri/2014/819453/.

11. Grabovac $S$, Grabovac $Ð$, Salaj T. Respiratorna insuficijencija uzrokovana laringokelom: prikaz slučaja. Medicina fluminensis 2018;54:74-9. 